\title{
Ectonucleoside triphosphate diphosphohydrolases and ecto-5'-nucleotidase in purinergic signaling: how the field developed and where we are now
}

\author{
Herbert Zimmermann ${ }^{1}$ (D) \\ Received: 1 September 2020 / Accepted: 12 November 2020 / Published online: 17 December 2020 \\ (C) The Author(s) 2020
}

\begin{abstract}
Geoffrey Burnstock will be remembered as the scientist who set up an entirely new field of intercellular communication, signaling via nucleotides. The signaling cascades involved in purinergic signaling include intracellular storage of nucleotides, nucleotide release, extracellular hydrolysis, and the effect of the released compounds or their hydrolysis products on target tissues via specific receptor systems. In this context ectonucleotidases play several roles. They inactivate released and physiologically active nucleotides, produce physiologically active hydrolysis products, and facilitate nucleoside recycling. This review briefly highlights the development of our knowledge of two types of enzymes involved in extracellular nucleotide hydrolysis and thus purinergic signaling, the ectonucleoside triphosphate diphosphohydrolases, and ecto-5'-nucleotidase.
\end{abstract}

Keywords Adenosine $\cdot$ ATP $\cdot$ Ecto-5'-nucleotidase $\cdot$ E-NTPDase $\cdot$ Geoffrey Burnstock $\cdot$ History

Herbert Zimmermann received his $\mathrm{PhD}$ in natural sciences from the University of Regensburg, Germany in 1971. Currently he is working as professor emeritus at the Department of Cell Biology and Neuroscience, Faculty of Biosciences at the Goethe University, Frankfurt am Main, Germany. His research interests include the molecular and cellular biology of components of the purinergic signaling pathway (ectoenzymes, receptors), adult neurogenesis, synaptic vesicle proteins, synaptic vesicle turnover.

\section{Introduction}

Ectonucleoside triphosphate diphosphohydrolases (ENTPDases) and ecto-5'-nucleotidase (eN) are only part of a broader spectrum of extracellular nucleotide-metabolizing enzymes, including ectonucleotide pyrophosphatase/phosphodiesterases, alkaline phosphatases, prostatic acid phosphatase, or extracellular ATP-regenerating enzymes [1, 2]. Yet, ENTPDases and eN have been the enzyme axis most extensively studied regarding purinergic signaling. Geoff Burnstock

This article is part of the Topical Collection on A Tribute to Professor Geoff Burnstock.

Herbert Zimmermann

h.zimmermann@bio.uni-frankfurt.de

1 Goethe University, Institute of Cell Biology and Neuroscience, Max-von-Laue-Str. 13, 60438 Frankfurt am Main, Germany maintained great interest in the mechanisms of extracellular nucleotide breakdown as these control purinergic receptor activity. This brief review is dedicated to Geoffrey Burnstock (1929-2020) as the leading scientist and promotor in the field, founder and chief editor of this journal, wonderful colleague, and friend.

\section{Nucleoside triphosphate diphosphohydrolases}

\section{Early studies}

Regarding the fate of ATP released from nerve endings, Geoff Burnstock, in his seminal review of 1972 [3], discards the possibility that it can directly be recycled. He strongly supports the notion that it is broken down by extracellularly located enzymes via ADP and AMP to adenosine, which is then recycled into the nerve ending for intracellular resynthesis of 
Fig. 1 Schematic representation of synthesis, storage, release, and inactivation of ATP at purinergic nerves as depicted by Burnstock for purinergic neuromuscular junctions in 1972 [3]. Reproduced with permission from the American Society for Pharmacology and Experimental Therapeutics

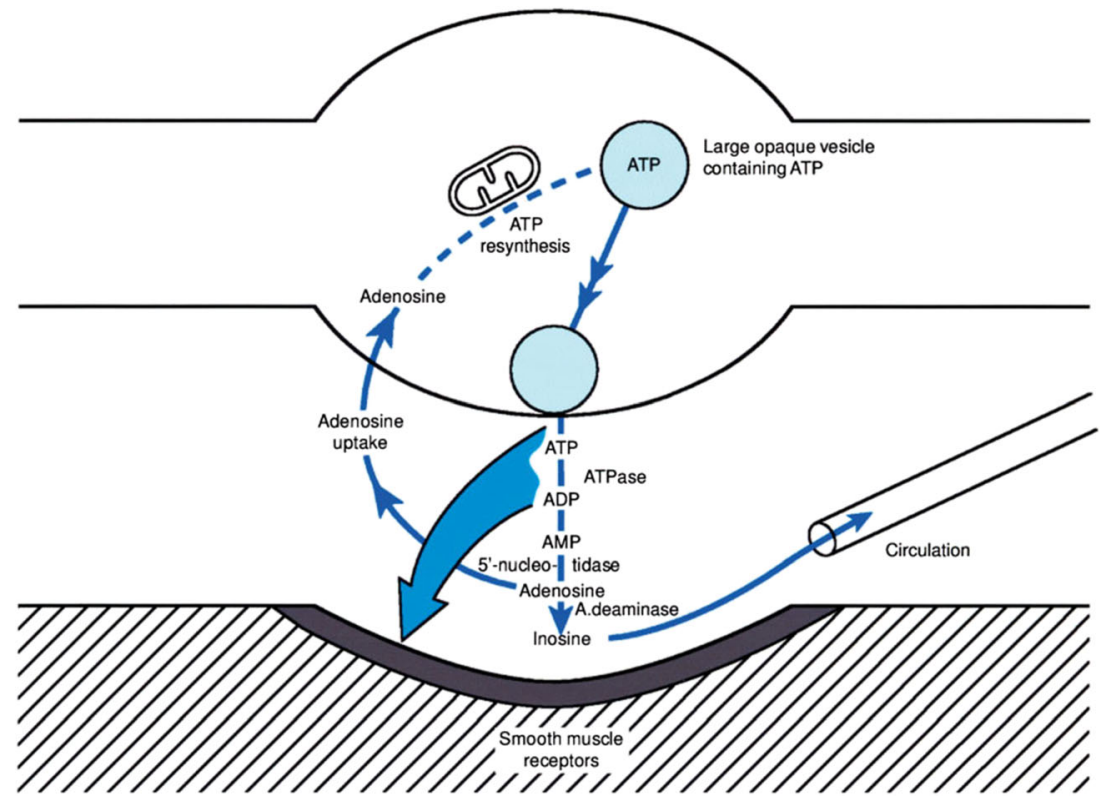

ATP. He develops a model of synthesis, storage, release, and inactivation of ATP at the purinergic neuromuscular junction that still holds today (Fig. 1).

Evidence for extracellular hydrolysis of ATP in tissue perfusates was provided already in the 1930s. But biochemical approaches to a mechanistic analysis were developed later. Since ATP is hydrolyzed intracellularly and by broken tissue, convincing evidence for cell surface-located ATP hydrolysis could initially only be obtained by analysis of dispersed and intact cells. First evidence was provided in 1945 in carefully washed bull spermatozoa by T. Mann in Cambridge [4]. More detailed reports followed this pioneering study [5, 6]. When analyzing nucleated avian erythrocytes, Wladimir A. Engelhardt and Tatjana Wenkstern realized that not only ATP but also ADP or ITP were hydrolyzed [7, 8]. Catalytic activity had an alkaline $\mathrm{pH}$ optimum and was blocked by EDTA (ethylenediaminetetraacetic acid). These two authors introduced the term ecto-ATPase in 1955 [9] as well as the terms ectoenzyme and ecto-apyrase (Engelhardt, 1958, held at the International Symposium on Enzyme Chemistry, Tokyo and Kyoto, 1957, [7] and Wenkstern and Engelhardt in 1959) [8].

\section{Objections and a solution}

Yet, the function of this "ectoenzyme" remained obscure. Nucleotides appeared not to be present in appreciable amounts in the extracellular medium. ATPase activity was solely known to relate to cellular energetics and cellular metabolism. Could it have something to do with active transport of substances across the plasma membrane or the control of cell permeability? [7]. This problem persisted for a very long time.
Biochemists would not agree that an energy-rich substance such as ATP would at all be released from cells under physiological conditions. And if so, the free enthalpy of hydrolysis had to be employed somehow for an energy-driven cellular process. It would not simply evaporate. This is the merit of Geoff Burnstock: extracellular nucleotide hydrolysis makes sense in the light of purinergic signaling.

\section{Biochemical analysis}

In spite of these uncertainties, an increasing number of studies using various cellular systems analyzed the catalytic properties of extracellular nucleotide hydrolysis. The results varied to some extent between individual studies. In retrospect, this is not at all surprising since several "ATPases" exist in the plasma membrane and, even more, several ectoenzymes capable of hydrolyzing extracellular ATP may coexist in the same tissue. But some consensus was achieved that the "enzyme" is a glycosylated membrane integral protein, that the underlying catalytic activity is activated by $\mathrm{Ca}^{2+}$ or $\mathrm{Mg}^{2+}$ in the millimolar range and inhibited by EDTA, and that catalytic activity is highly sensitive to SH reagents but insensitive to inhibitors at concentrations which inhibit mitochondrial ATPase and $\mathrm{Na}^{+} / \mathrm{K}^{+}$-ATPase. $K_{\mathrm{m}}$ values for ATP were in the low millimolar range. Both purine and pyrimidine nucleotides were hydrolyzed, albeit with differing efficiency. In the 1980s, first attempts were made to purify the ectoenzyme(s). The high detergent sensitivity turned out to be a major obstacle for enzyme purification because the monomeric forms retain little catalytic activity. These early studies were summarized in several reviews [10-20]. 


\section{Purification and molecular cloning}

The rise of molecular genetics made all the difference. Sequence information from purified proteins made it possible to identify the encoding cDNA, followed by heterologous expression and analysis of the protein. Moreover, sequence comparison allowed the identification of paralogues and of orthologues in other species. This was achieved by converging efforts of several laboratories. An ATP diphosphohydrolase was first purified to homogeneity by Christoforidis et al. in 1995 [21] from human placenta. It turned out that the peptide sequences obtained corresponded to a functionally as yet unidentified lymphoid cell activation protein (Cluster of differentiation 39, CD39) that had been cloned and sequenced shortly before [22]. Of note, this was not known to Christoforidis et al. when they submitted their paper. Moreover, a soluble apyrase was cloned from potato tubers in 1996 which was found to be related to CD39 and known apyrases from other organisms. Apparently, there was a group of widely conserved enzymes whose sequences shared typical features such as the "apyrase conserved regions" [23]. In the same year, this laboratory demonstrated ecto-apyrase activity of CD39 by expression in COS-7 cells [24]. Moreover, peptide sequences from a bovine aorta-derived ATP diphosphohydrolase revealed identity with CD39 [25]. Similarly, expression of CD39 in COS-1 cells confirmed its ecto-ADPase activity and highlighted its role as a prime endothelial thromboregulator [26]. The ice was broken. While it was originally thought that there was only a single mammalian "ecto-apyrase," a paralog was soon sequenced and expressed by Kegel et al., in 1997 [27]. Surprisingly, it turned out to preferentially hydrolyze ATP and appeared to function as an "ecto-ATPase" rather than an "ecto-apyrase" [28]. Moreover, four paralogs were identified in 1998 in the human genome, demonstrating that an entire gene and protein family must exist [29]. We now know that eight paralogs are encoded in the mammalian genome, all hydrolyzing nucleotides only, four of which are typical surface-located ectonucleotidases (NTPDase1, 2, 3, and 8) (Fig. 2). Related enzymes are found in invertebrates, plants, yeast, protozoans, and bacteria [30]. ENTPDases share common sequence motifs with members of the ASKHA (acetate and sugar kinases/Hsc70/actin) superfamily of phosphotransferases $[1,31,32]$.

The years following envisaged impressive progress in further characterizing proteins and genes, using mutation studies, developing inhibitors, resolving atomic structures, and analyzing their function in physiological and pathophysiological conditions. The four surface-located E-NTPDases are glycosylated and share their general membrane topology with two transmembrane domains, which play an important role in function and regulation of the enzymes in addition to anchoring the proteins in the plasma membrane (Fig. 2). The formation of oligomers is essential for full catalytic activity. The biochemical properties of the E-NTPDases, their splice variants, and their tissue distribution have been reviewed in detail $[1,19,20,32-36]$.

\section{Confusing nomenclature}

Considerable confusion existed regarding nomenclature. Different names had been assigned by different groups and to individual paralogues. Moreover, the often-used term ecto-
Fig. 2 Membrane topology of NTPDases 1, 2, 3, and 8 and eN (ecto-5'-nucleotidase). The boxes in the NTPDase extracellular loop represent the position of the apyrase conserved regions. $\mathrm{eN}$ is GPI-anchored. The GPI anchor may be cleaved by endogenous phospholipases resulting in the release of the enzyme into the interstitial space. NTPDases have the potential to form homooligomeric complexes (dimers to tetramers). eN exists and functions as a noncovalent dimer [1]. The hydrolysis cascade is shown for ATP to adenosine. But it applies also to other nucleoside triphosphates (NTP $\rightarrow \mathrm{NDP} \rightarrow$ $\mathrm{NMP} ; \mathrm{NMP} \rightarrow$ nucleoside). Purinergic receptors activated by nucleotides and adenosine are indicated below

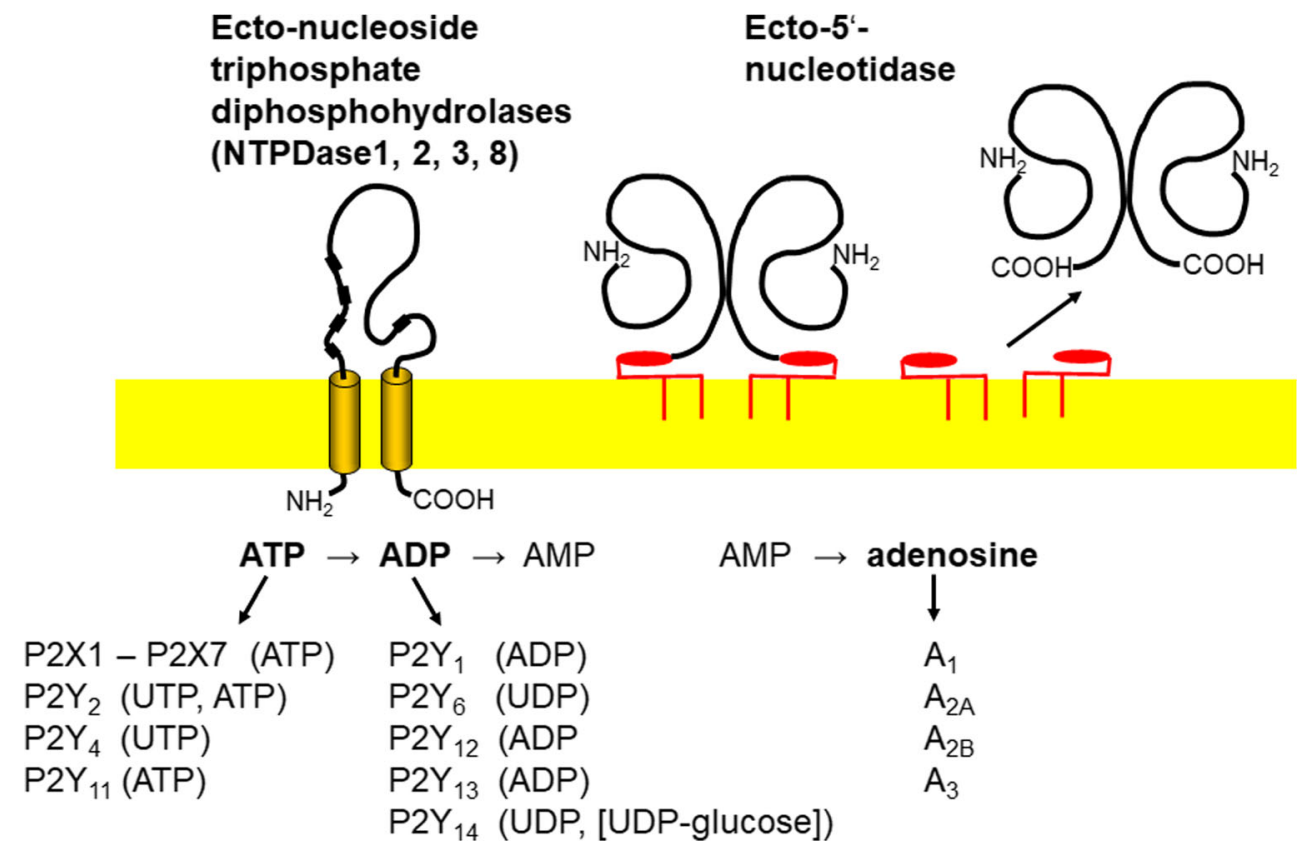


ATPase for the ecto-ATP diphosphohydrolase appeared misleading since it disguised the fact that also ADP (an agonist of several P2Y receptors) is hydrolyzed with AMP as the final hydrolysis product. Moreover, not only ATP and ADP but also other nucleoside tri- and diphosphates were hydrolyzed. The author of this article thus put together a nomenclature committee which finally met at the conference on "EctoATPases and related ectonucleotidases" held in Diepenbeek, Belgium, in 1999 where it was agreed to apply a strictly biochemical enzyme nomenclature and to name this new protein family ectonucleoside triphosphate diphosphohydrolase family (E-NTPDase family) (EC: EC 3.6.1.5) and its individual members NTPDase1, NTPDase2, and so on [35, 37]. While the name CD39 is frequently used for NTPDase1 in studies merely relating to its catalytic function, the author holds that the enzyme nomenclature should be applied.

\section{Crystal structures and catalytic cycle}

Of central importance for understanding the molecular mechanisms of hydrolysis and the development of inhibitors was the resolution of crystal structures of E-NTPDases. First structures were obtained of the extracellular domain of rat NTPDase2 [38] and a related soluble NTPDase of the pathogenic bacterium Legionella pneumophila (LpNTPDase1), which is secreted into the replication vacuole [39]. The crystal structures revealed a pseudo-symmetrical arrangement of two extended RNase $\mathrm{H}$ fold repeats that is also found in other members of the actin structural superfamily. Two structural domains are formed which are characterized by a central mixed $\beta$-sheet and a peripheral layer of mainly $\alpha$-helices. Co-crystals with substrate analogs allowed to identify the catalytic site and to propose a catalytic mechanism involving the individual apyrase conserved regions. The same catalytic site is employed in the hydrolysis of nucleoside di- and triphosphates. During the catalytic cycle, the domains undergo rotational movements supporting the idea that the previously described impact of transmembrane helix dynamics on activity is achieved by coupling to a domain motion (Fig. 3) [40, 41].

\section{Development of inhibitors}

Multiple studies have highlighted the involvement of ectonucleotidases in pathological conditions. The interplay of ectonucleotidases with the nucleotide and adenosine receptor systems has come increasingly into focus. Alterations in extracellular nucleotide and adenosine levels can increase or decrease $\mathrm{P} 2$ receptor and $\mathrm{P} 1$ receptor activity. The development of potent and subtype-specific ectonucleotidase inhibitors thus appeared mandatory [42]. This was a field Geoff Burnstock was particularly interested in. In the 1990s, his group published a series of papers on "ecto-ATPases," which mostly focused on the characterization of enzyme inhibitors [13]. The development of potent and specific inhibitors turned out to be a challenge. Inhibitors should not affect nucleotide receptors or other types of ectonucleotidaseswhich all share nucleotide-binding sites. And they should not become hydrolyzed. While several E-NTPDase inhibitors have been developed, potent subtype-specific inhibitors are scarce. Most of these are ATP analogs. Other classes concern polyoxometalates, negatively charged metal complexes, anthraquinone derivatives, Schiff bases of tryptamine, quinoline derivatives, and thiadiazolopyrimidones [43-46]. The elucidation of the molecular structure of mammalian E-NTPDases now permits a structure-guided approach of inhibitor development with the ultimate goal of drug design [47].

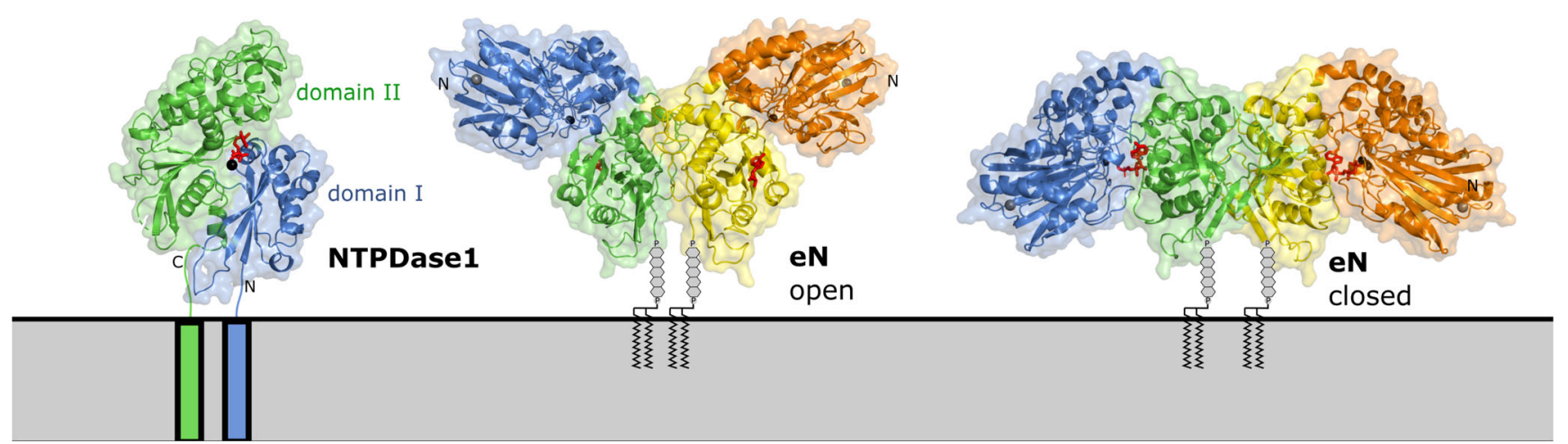

Fig. 3 Ectodomain structure of NTPDase1 and eN. To mark the active site of rat NTPDase1 (chain A of protein data bank [pdb] id 3zx3), the non-hydrolysable ATP analogue AMPPNP ( $\beta, \gamma$-imidoadenosine 5'triphosphate) (red) and a calcium ion (black sphere) have been superimposed from rat NTPDase 2 structure (pdb id $3 \mathrm{cja}$ ). For the homodimeric eN, the domains of one monomer are depicted in blue and green, whereas the other subunit is shown in yellow and orange.
The catalytic zinc ions are shown in black and the structural $\mathrm{Ca}^{2+}$ ions in gray. Adenosine (red) is bound to the C-terminal domains of the open state structure of eN (pdb id 4h2i), and AMPCP (adenosine 5'-[ $\alpha, \beta$ methylene]diphosphate) (red) is bound to the active site in the closed state structure (pdb id 4h2i). The figure was kindly provided by Norbert Sträter, Leipzig, Germany 


\section{Therapeutic approaches}

Equally important were studies which generated subtypespecific antibodies for analyzing the distribution of the individual enzymes in mammalian tissues [42] and the generation of mice in which individual NTPDases were deleted. The first gene encoding a mammalian NTPDase deleted from the germline was Entpd1 [48]. The study proved its fundamental role in hemostasis and thrombosis. This was followed by the deletion of Entpd2, the gene encoding NTPDase2, which allowed to analyze the function of the enzyme in taste buds [49], followed by the deletion of NTPDas3 [50]. Moreover, transgenic overexpression of NTPDase1 in mice or pigs permitted insight into its role in multiple organ systems. One outcome was the attenuation of myocardial infarction by decreasing infarct size [51-53], confirming previous results emphasizing the important role of ATP hydrolysis and in particular of NTPDase 1 in the interplay with nucleotide receptors in the control of vascular function [54, 55]. Moreover, the benefit of administration of soluble apyrase or of induction of NTPDase1 by adenoviral vectors on several models of organ transplantation has been investigated [56]. By now, multiple organ systems and disease models including cancer, immunosuppression, and inflammation have been studied. Recently, the clinical evaluation of anti-NTPDase 1 monoclonal antibodies for cancer therapy has been initiated [57]. Only a selection of overviews can be cited here [58-70].

\section{Ecto-5'-nucleotidase}

\section{Biochemical properties}

This enzyme was first described in extracts of heart tissue by J.L. Reis in 1934 who named it "5-nucleotidase" [71]. He realized that "5-nucleotidase" differs from nonspecific phosphatases already known at the time as it showed high specificity towards nucleoside monophosphates (Fig. 2). In contrast to NTPDases, 5'-nucleotidase was intensively investigated early on $[72,73]$. In 1974, it was shown that 5 '-nucleotidase is an ectoenzyme in several cell types [74-76]. As a result of adenosine production, scavenging of extracellular nucleotides (including nutrition), involvement in vasodilation, neurotransmission, or hemostasis had been described [77]. The glycoprotein $\mathrm{eN}$ is a major enzyme producing adenosine from extracellular AMP and thus for activation of adenosine receptors [78]. Before this context had been elucidated, eN was widely used as a membrane marker and for the analysis of plasma membrane recycling [79]. Eukaryotic eN functions as a noncovalent dimeric $\mathrm{Zn}^{2+}$-binding protein, with reported $K_{\mathrm{m}}$ values for AMP between 1 and $50 \mu \mathrm{M}$. ATP and ADP are competitive inhibitors of mammalian eN with $K_{\mathrm{i}}$ values in the low micromolar range. This is important, since due to feed forward inhibition, adenosine formation from ATP or ADP will be considerably delayed until extracellular nucleotide levels have fallen into the micromolar range [1].

While it was originally assumed that $\mathrm{eN}$ is an integral membrane protein, it was shown by several groups that it can be released by phosphatidylinositol-specific phospholipase $\mathrm{C}$ and thus must be anchored to the plasma membrane by a glycosylphosphatidylinositol (GPI) anchor [80]. Primary structures were first obtained for the enzyme from rat liver [81], human placenta [82], and the brain of the electric ray [83]. Sequence comparison revealed that $\mathrm{eN}$ can be grouped into the calcineurin superfamily of dinuclear metallophosphatases with multiple members in prokaryotes, invertebrates, and vertebrates. The molecular and functional properties of eN have been reviewed $[1,84,85]$. Interestingly, humans express several transcript variants [86].

\section{Nomenclature}

As for NTPDases, the nomenclature of 5'-nucleotidases was initially confusing. Apparently, there existed also soluble forms. Whereas some shared properties with eN, others clearly differed regarding catalytic properties. Therefore, an attempt was made by the author of this article to classify the various types of 5 -nucleotidases, and a new nomenclature was suggested [80]. One of the soluble forms was assigned to eN, generated by cleavage of the GPI anchor. At that time, no sequence information was available for soluble 5 '-nucleotidases. After the sequences of the six intracellular and soluble 5 '-nucleotidases had been revealed, the nomenclature was adapted accordingly [87]. CD73 (cluster of differentiation 73 ) is frequently used as an alternative name in studies addressing eN.

\section{Crystal structures and inhibitors}

Crystal structures were first obtained for Escherichia coli 5'nucleotidase which served as a model for mammalian eN [88, 89]. In 2012, crystal structures of both the open and closed form of human eN lacking the membrane anchor were determined $[90,91]$. These studies revealed an extensive active site closure movement involving the $\mathrm{N}$ - and $\mathrm{C}$-terminal domains of the eN monomer, which is thought to be necessary for human $\mathrm{eN}$ catalysis, permitting substrate binding and product release (Fig. 3). In addition, the active site closure movement may control eN substrate specificity towards AMP and thereby inhibition by ADP and ATP. It is now possible to design structure-based potent and selective small molecule inhibitors for future drug development. This is important as the hydrolysis product adenosine is involved in numerous pathologies. Progress had been made with several naturally occurring phenolic compounds and flavonoids or anthraquinone dye 
derivatives $[44,92]$. A catalytically active soluble rat eN purified after heterologous expression in insect cells [93] has been widely used for drug screening. Recently, small molecule inhibitors with subnanomolar $K_{\mathrm{i}}$ values at human and rat $\mathrm{eN}$ could be developed, which are derivatives of purine and pyrimidine nucleotides. Moreover, high-resolution co-crystal structures revealed insight into the binding mode and represent an excellent basis for drug development [57, 94-96]. Similarly, monoclonal antibodies are applied as inhibitors of $\mathrm{eN}$ and may be employed as therapeutic agents [97-99].

\section{Highly relevant for adenosine signaling}

Ecto-5'-nucleotidase plays an important role in tissue homeostasis and pathology in many organ systems and in acute and chronic inflammation [2]. This is particularly relevant in the context of acute and chronic types of injury, where $\mathrm{eN}$ is essential for maintaining tissue integrity and recovery [69, 86]. Important insight was obtained by targeted disruption of the $N t 5 e$ gene in mice revealing that vascular leakage was significantly increased in multiple organs and identifying the enzyme as a critical mediator of vascular leakage in vivo [100]. Moreover, genetic deletion of $\mathrm{eN}$ in mice is associated with a proinflammatory phenotype suggesting that eNmediated adenosine formation represents a key innate mechanism to attenuate tissue inflammation [101, 102]. Behavioral analyses of eN knockout mice suggest that $\mathrm{eN}$ is involved in the regulation of learning and memory and psychomotor coordination [103]. Numerous studies analyzing Nt5e-depleted mice followed [85]. More recently, eN has gained considerable attention as a target for cancer treatment. Both ATP and adenosine accumulate at high levels in inflammatory and tumor sites. They play a central role in immune cell regulation and tumor cell proliferation. $\mathrm{eN}$ is upregulated in various types of cancer. The immunosuppressive adenosine impairs antitumor responses and enhances tumor growth and metastasis. Targeted eN (as well as NTPDase1) therapy using inhibitors is therefore an important approach to effectively control tumor growth [57, 99, 104-106].

\section{Résumé}

Fifty years after establishing the concept of purinergic signaling by Geoff Burnstock and after about 80 years following the discovery of the two types of ectonucleotidases and numerous studies which elucidated their functional and structural properties, the time is now ripe for harvest. This concerns in particular the application of new tools for identifying the pathophysiological involvement of the enzymes in purinergic signaling in the various organ systems and the development of tailored therapies for human diseases.

Authors' contributions Not applicable.
Funding Open Access funding enabled and organized by Projekt DEAL.

Data availability Not applicable.

\section{Compliance with ethical standards}

Conflict of interest The author declares that he has no conflict of interest.

Code availability Not applicable.

Open Access This article is licensed under a Creative Commons Attribution 4.0 International License, which permits use, sharing, adaptation, distribution and reproduction in any medium or format, as long as you give appropriate credit to the original author(s) and the source, provide a link to the Creative Commons licence, and indicate if changes were made. The images or other third party material in this article are included in the article's Creative Commons licence, unless indicated otherwise in a credit line to the material. If material is not included in the article's Creative Commons licence and your intended use is not permitted by statutory regulation or exceeds the permitted use, you will need to obtain permission directly from the copyright holder. To view a copy of this licence, visit http://creativecommons.org/licenses/by/4.0/.

\section{References}

1. Zimmermann H, Zebisch M, Sträter N (2012) Cellular function and molecular structure of ecto-nucleotidases. Purinergic Signal 8: 437-502. https://doi.org/10.1007/s11302-012-9309-4

2. Yegutkin GG (2014) Enzymes involved in metabolism of extracellular nucleotides and nucleosides: functional implications and measurement of activities. Crit Rev Biochem Mol Biol 49:473497. https://doi.org/10.3109/10409238.2014.953627

3. Burnstock G (1972) Purinergic nerves. Pharmacol Rev 24:509_ 581

4. Mann T (1945) Studies on the metabolism of semen: 1. General aspects. Occurrence and distribution of cytochrome, certain enzymes and coenzymes. Biochem J 39:451-458

5. Zimmermann H, Mishra SK, Shukla V, Langer D, Gampe K et al (2007) Ecto-nucleotidases, molecular properties and functional impact. An. de la Real Acad Nac de Farm 73:537-566

6. Zimmermann H (2008) ATP and acetylcholine, equal brethren. Neurochem Int 52:634-648. https://doi.org/10.1016/j.neuint. 2007.09.004

7. Engelhardt WA (1958) Enzymes as structural elements of physiological mechanisms. I.U.B. Symp Ser 2:163-168

8. Wenkstern TW, Engelhardt WA (1959) The adenosine polyphosphatase localized on the surface of nucleated red corpuscles. Folia Haematol Int Mag Klin Morphol Blutforsch 76:422431

9. Venkstern TV, Engelgardt VA (1955) Poverkhnostnolokalizovannaia adenozinpolifosfataza iadernykh eritrotsitov (adenosine-polyphosphatase of surfaces of nuclear erythrocytes). Dokl Akad Nauk SSSR 102:133-136

10. Banerjee RK (1981) Ecto-ATPase. Mol Cell Biochem 37:91-99. https://doi.org/10.1007/BF02354932

11. Pearson JD (1985) Ectonucleotidases: measurement of activities and use of inhibitors. Methods Pharmacol 6:83-107

12. Dhalla NS, Zhao D (1988) Cell membrane $\mathrm{Ca}^{2+} / \mathrm{Mg}^{2+}$ ATPase. Prog Biophys Mol Biol 52:1-37. https://doi.org/10.1016/00796107(88)90006-5 
13. Ziganshin AU, Hoyle CHV, Burnstock G (1994) Ecto-enzymes and metabolism of extracellular ATP. Drug Dev Res 32:134-146. https://doi.org/10.1002/ddr.430320303

14. Plesner L (1995) Ecto-ATPases: identities and functions. Int Rev Cytol 158:141-214. https://doi.org/10.1016/s0074-7696(08) 62487-0

15. Sarkis JJF, Battastini AMO, Oliveira EM et al (1995) ATP diphosphohydrolases: an overview. Ciência Cultura 47:131-136

16. Beaudoin AR, Sévigny J, Picher M (1996) ATPdiphosphohydrolases, apyrases, and nucleotide phosphohydrolases: biochemical properties and functions. Biomembranes 5:369-401

17. Zimmermann H (1996) Biochemistry, localization and functional roles of ecto-nucleotidases in the nervous system. Prog Neurobiol 49:589-618. https://doi.org/10.1016/0301-0082(96)00026-3

18. Zimmermann H (1996) Extracellular purine metabolism. Drug Dev Res 39:337-352. https://doi.org/10.1002/(SICI)10982299(199611/12)39:3/4<337:AID-DDR15>3.0.CO;2-Z

19. Zimmermann H (2000) Extracellular metabolism of ATP and other nucleotides. Naunyn Schmiedeberg's Arch Pharmacol 362: 299-309. https://doi.org/10.1007/s002100000309

20. Zimmermann H, Braun N (1999) Ecto-nucleotidases - molecular structures, catalytic properties, and functional roles in the nervous system. Prog Brain Res 120:371-385

21. Christoforidis S, Papamarcaki T, Galaris D, Kellner R, Tsolas O (1995) Purification and properties of human placental ATP diphosphohydrolase. Eur J Biochem 234:66-74. https://doi.org/ 10.1111/j.1432-1033.1995.066_c.x

22. Maliszewski CR, Delespesse GJ, Schoenborn MA, Armitage RJ, Fanslow WC, Nakajima T, Baker E, Sutherland GR, Poindexter K, Birks C (1994) The CD39 lymphoid cell activation antigen. Molecular cloning and structural characterization. J Immunol 153: 3574-3583

23. Handa M, Guidotti G (1996) Purification and cloning of a soluble ATP-diphosphohydrolase (apyrase) from potato tubers (Solanum tuberosum). Biochem Biophys Res Commun 218:916-923. https://doi.org/10.1006/bbrc.1996.0162

24. Wang TF, Guidotti G (1996) CD39 is an ecto- $\left(\mathrm{Ca}^{2+}, \mathrm{Mg}^{2+}\right)$-apyrase. J Biol Chem 271:9898-9901

25. Kaczmarek E, Koziak K, Sévigny J, Siegel JB, Anrather J, Beaudoin AR, Bach FH, Robson SC (1996) Identification and characterization of CD39/vascular ATP diphosphohydrolase. J Biol Chem 271:33116-33122. https://doi.org/10.1074/jbc.271. 51.33116

26. Marcus AJ, Broekman MJ, Drosopoulos JH, Islam N, Alyonycheva TN, Safier LB, Hajjar KA, Posnett DN, Schoenborn MA, Schooley KA, Gayle RB, Maliszewski CR (1997) The endothelial cell ecto-ADPase responsible for inhibition of platelet function is CD39. J Clin Invest 99:1351-1360. https://doi.org/10.1172/JCI119294

27. Kegel B, Braun N, Heine P et al (1997) An ecto-ATPase and an ecto-ATP diphosphohydrolase are expressed in rat brain. Neuropharmacology 36:1189-1200. https://doi.org/10.1016/ s0028-3908(97)00115-9

28. Heine P, Braun N, Heilbronn A, Zimmermann H (1999) Functional characterization of rat ecto-ATPase and ecto-ATP diphosphohydrolase after heterologous expression in $\mathrm{CHO}$ cells. Eur J Biochem 262:102-107. https://doi.org/10.1046/j.14321327.1999.00347.x

29. Chadwick BP, Frischauf AM (1998) The CD39-like gene family: identification of three new human members (CD39L2, CD39L3, and CD39L4), their murine homologues, and a member of the gene family from Drosophila melanogaster. Genomics 50:357367. https://doi.org/10.1006/geno.1998.5317

30. Wang T-F, Handa M, Guidotti G (1998) Structure and function of ectoapyrase (CD39). Drug Dev Res 45:245-252. https://doi.org/
10.1002/(SICI) 1098-2299(199811/12)45:3/4<245:AIDDDR22>3.0.CO;2-U

31. Smith TM, Kirley TL (1999) Site-directed mutagenesis of a human brain ecto-apyrase: evidence that the E-type ATPases are related to the actin/heat shock 70/sugar kinase superfamily. Biochemistry 38:321-328. https://doi.org/10.1021/bi9820457

32. Knowles AF (2011) The GDA1_CD39 superfamily: NTPDases with diverse functions. Purinergic Signal 7:21-45. https://doi.org/ 10.1007/s11302-010-9214-7

33. Kirley TL, Crawford PA, Smith TM (2006) The structure of the nucleoside triphosphate diphosphohydrolases (NTPDases) as revealed by mutagenic and computational modeling analyses. Purinergic Signal 2:379-389. https://doi.org/10.1007/s11302005-5301-6

34. Robson SC, Sévigny J, Zimmermann H (2006) The E-NTPDase family of ectonucleotidases: structure function relationships and pathophysiological significance. Purinergic Signal 2:409-430. https://doi.org/10.1007/s11302-006-9003-5

35. Zimmermann H (2001) Ectonucleotidases: some recent developments and a note on nomenclature. Drug Dev Res 52:44-56. https://doi.org/10.1002/ddr.1097

36. Zimmermann H (2001) Ectonucleotidases. In: Abbracchio MP, Williams M (eds) Purinergic and pyrimidergic signalling I. Springer-Verlag, Berlin, Heidleberg, New York, pp 209-250

37. Zimmermann H, Beaudoin AR, Bollen M et al (2000) Proposed nomenclature for two novel nucleotide hydrolyzing enzyme families expressed on the cell surface. In: Vanduffel L, Lemmens R (eds) Ecto-ATPases and related ectonucleotidases. Shaker Publishing B.V, Maastricht, The Netherlands, pp 1-8

38. Zebisch M, Sträter N (2008) Structural insight into signal conversion and inactivation by NTPDase2 in purinergic signaling. Proc Natl Acad Sci U S A 105:6882-6887. https://doi.org/10.1073/ pnas.0802535105

39. Vivian JP, Riedmaier P, Ge H, le Nours J, Sansom FM, Wilce MCJ, Byres E, Dias M, Schmidberger JW, Cowan PJ, d'Apice AJF, Hartland EL, Rossjohn J, Beddoe T (2010) Crystal structure of a Legionella pneumophila ecto-triphosphate diphosphohydrolase, a structural and functional homolog of the eukaryotic NTPDases. Structure 18:228-238. https://doi.org/10. 1016/j.str.2009.11.014

40. Zebisch M, Krauss M, Schäfer P, Sträter N (2012) Crystallographic evidence for a domain motion in rat nucleoside triphosphate diphosphohydrolase (NTPDase) 1. J Mol Biol 415: 288-306. https://doi.org/10.1016/j.jmb.2011.10.050

41. Zebisch M, Krauss M, Schäfer P, Lauble P, Sträter N (2013) Crystallographic snapshots along the reaction pathway of nucleoside triphosphate diphosphohydrolases. Structure 21:1460-1475. https://doi.org/10.1016/j.str.2013.05.016

42. Kukulski F, Lévesque SA, Sévigny J (2011) Impact of ectoenzymes on P2 and P1 receptor signaling. Adv Pharmacol 61:263-299. https://doi.org/10.1016/B978-0-12-385526-8. 00009-6

43. Al-Rashida M, Iqbal J (2014) Therapeutic potentials of ectonucleoside triphosphate diphosphohydrolase, ecto-nucleotide pyrophosphatase/phosphodiesterase, ecto-5'-nucleotidase, and alkaline phosphatase inhibitors. Med Res Rev 34:703-743. https:// doi.org/10.1002/med.21302

44. Baqi Y (2015) Ecto-nucleotidase inhibitors: recent developments in drug discovery. Mini Rev Med Chem 15:21-33. https://doi.org/ 10.2174/1389557515666150219115141

45. Lee S-Y, Fiene A, Li W, Hanck T, Brylev KA, Fedorov VE, Lecka J, Haider A, Pietzsch HJ, Zimmermann H, Sévigny J, Kortz U, Stephan H, Müller CE (2015) Polyoxometalatespotent and selective ecto-nucleotidase inhibitors. Biochem Pharmacol 93:171-181. https://doi.org/10.1016/j.bcp.2014.11. 002 
46. Afzal S, Zaib S, Jafari B, Langer P, Lecka J, Sévigny J, Iqbal J (2019) Highly potent and selective ectonucleoside triphosphate diphosphohydrolases (ENTPDase1, 2, 3 and 8) inhibitors having 2-substituted-7-trifluoromethyl-thiadiazolopyrimidones scaffold. Med Chem 16:689-702. https://doi.org/10.2174/ 1573406415666190614095821

47. Zebisch M, Baqi Y, Schäfer P, Müller CE, Sträter N (2014) Crystal structure of NTPDase2 in complex with the sulfoanthraquinone inhibitor PSB-071. J Struct Biol 185:336341. https://doi.org/10.1016/j.jsb.2014.01.005

48. Enjyoji K, Sévigny J, Lin Y, Frenette PS, Christie PD, Esch JSA II, Imai M, Edelberg JM, Rayburn H, Lech M, Beeler DL, Csizmadia E, Wagner DD, Robson SC, Rosenberg RD (1999) Targeted disruption of cd39/ATP diphosphohydrolase results in disordered hemostasis and thromboregulation. Nat Med 5:1010 1017. https://doi.org/10.1038/12447

49. Vandenbeuch A, Anderson CB, Parnes J, Enjyoji K, Robson SC, Finger TE, Kinnamon SC (2013) Role of the ectonucleotidase NTPDase2 in taste bud function. Proc Natl Acad Sci U S A 110: 14789-14794. https://doi.org/10.1073/pnas.1309468110

50. McCoy E, Street S, Taylor-Blake B et al (2014) Deletion of ENTPD3 does not impair nucleotide hydrolysis in primary somatosensory neurons or spinal cord. F1000Res 3:163. https:// doi.org/10.12688/f1000research.4563.2

51. Dwyer KM, Robson SC, Nandurkar HH, Campbell DJ, Gock H, Murray-Segal LJ, Fisicaro N, Mysore TB, Kaczmarek E, Cowan PJ, d'Apice AJF (2004) Thromboregulatory manifestations in human CD39 transgenic mice and the implications for thrombotic disease and transplantation. J Clin Invest 113:1440-1446. https:// doi.org/10.1172/JCI19560

52. Cai M, Huttinger ZM, He H, Zhang W, Li F, Goodman LA, Wheeler DG, Druhan LJ, Zweier JL, Dwyer KM, He G, d'Apice AJF, Robson SC, Cowan PJ, Gumina RJ (2011) Transgenic over expression of ectonucleotide triphosphate diphosphohydrolase-1 protects against murine myocardial ischemic injury. J Mol Cell Cardiol 51:927-935. https://doi.org/10.1016/j.yjmcc.2011.09.003

53. Wheeler DG, Joseph ME, Mahamud SD, Aurand WL, Mohler PJ, Pompili VJ, Dwyer KM, Nottle MB, Harrison SJ, d'Apice AJF, Robson SC, Cowan PJ, Gumina RJ (2012) Transgenic swine: expression of human CD39 protects against myocardial injury. $\mathrm{J}$ Mol Cell Cardiol 52:958-961. https://doi.org/10.1016/j.yjmcc. 2012.01.002

54. Marcus AJ, Broekman MJ, Drosopoulos JHF, Olson KE, Islam N, Pinsky DJ, Levi R (2005) Role of CD39 (NTPDase-1) in thromboregulation, cerebroprotection, and cardioprotection. Semin Thromb Hemost 31:234-246. https://doi.org/10.1055/s2005-869528

55. Gorman MW, Rooke GA, Savage MV, Jayasekara MPS, Jacobson KA, Feigl EO (2010) Adenine nucleotide control of coronary blood flow during exercise. Am J Physiol Heart Circ Physiol 299:H1981-H1989. https://doi.org/10.1152/ajpheart. 00611.2010

56. Robson SC, Wu Y, Sun X, Knosalla C, Dwyer K, Enjyoji K (2005) Ectonucleotidases of CD39 family modulate vascular inflammation and thrombosis in transplantation. Semin Thromb Hemost 31:217-233. https://doi.org/10.1055/s-2005-869527

57. Jeffrey JL, Lawson KV, Powers JP (2020) Targeting metabolism of extracellular nucleotides via inhibition of ecto-nucleotidases CD73 and CD39. J Med Chem. https://doi.org/10.1021/acs. jmedchem.0c01044

58. Dwyer KM, Deaglio S, Gao W, Friedman D, Strom TB, Robson SC (2007) CD39 and control of cellular immune responses. Purinergic Signal 3:171-180. https://doi.org/10.1007/s11302006-9050-y

59. Schetinger MRC, Morsch VM, Bonan CD, Wyse ATS (2007) NTPDase and 5 '-nucleotidase activities in physiological and disease conditions: new perspectives for human health. Biofactors 31:77-98. https://doi.org/10.1002/biof.5520310205

60. Deaglio S, Robson SC (2011) Ectonucleotidases as regulators of purinergic signaling in thrombosis, inflammation, and immunity. Adv Pharmacol 61:301-332. https://doi.org/10.1016/B978-0-12385526-8.00010-2

61. Zimmermann H (2011) Purinergic signaling in neural development. Semin Cell Dev Biol 22:194-204. https://doi.org/10.1016/ j.semcdb.2011.02.007

62. Ghiringhelli F, Bruchard M, Chalmin F, Rébé C (2012) Production of adenosine by ectonucleotidases: a key factor in tumor immunoescape. J Biomed Biotechnol 2012:473712473719. https://doi.org/10.1155/2012/473712

63. Chernogorova P, Zeiser R (2012) Ectonucleotidases in solid organ and allogeneic hematopoietic cell transplantation. J Biomed Biotechnol 2012:208204-208217. https://doi.org/10.1155/2012/ 208204

64. Vaughn BP, Robson SC, Longhi MS (2014) Purinergic signaling in liver disease. Dig Dis 32:516-524. https://doi.org/10.1159/ 000360498

65. Takenaka MC, Robson S, Quintana FJ (2016) Regulation of the T cell response by CD39. Trends Immunol 37:427-439. https://doi. org/10.1016/j.it.2016.04.009

66. Longhi MS, Moss A, Jiang ZG, Robson SC (2017) Purinergic signaling during intestinal inflammation. J Mol Med 95:915925. https://doi.org/10.1007/s00109-017-1545-1

67. Kishore BK, Robson SC, Dwyer KM (2018) CD39-adenosinergic axis in renal pathophysiology and therapeutics. Purinergic Signal 14:109-120. https://doi.org/10.1007/s11302-017-9596-x

68. Vuerich M, Robson SC, Longhi MS (2019) Ectonucleotidases in intestinal and hepatic inflammation. Front Immunol 10:507. https://doi.org/10.3389/fimmu.2019.00507

69. Dwyer KM, Kishore BK, Robson SC (2020) Conversion of extracellular ATP into adenosine: a master switch in renal health and disease. Nat Rev Nephrol 16:509-524. https://doi.org/10.1038/ s41581-020-0304-7

70. Wang S, Gao S, Zhou D, Qian X, Luan J, Lv X (2020) The role of the CD39-CD73-adenosine pathway in liver disease. J Cell Physiol. https://doi.org/10.1002/jcp.29932

71. Reis JL (1934) La nucléotidase et sa relation avec la désamination des nucleotides dans la coeur et dans le muscle. Bull Soc Chim Biol 16:385-399

72. Bodansky O, Schwartz MK (1968) 5'-Nucleotidase. Adv Clin Chem 11:277-328

73. Sunderman FW (1990) The clinical biochemistry of 5'-nucleotidase. Ann Clin Lab Sci 20:123-139

74. DePierre JW, Karnovsky ML (1974) Ecto-enzymes of the Guinea pig polymorphonuclear leukocyte. I. Evidence for an ectoadenosine monophosphatase, adenosine triphosphatase, and -pnitrophenyl phosphates. J Biol Chem 249:7111-7120

75. DePierre JW, Karnovsky ML (1974) Ecto-enzyme of granulocytes: 5'-nucleotidase. Science 183:1096-1098. https:// doi.org/10.1126/science.183.4129.1096

76. Trams EG, Lauter CJ (1974) On the sidedness of plasma membrane enzymes. Biochim Biophys Acta 345:180-197. https://doi. org/10.1016/0005-2736(74)90257-0

77. Stanley KK, Newby AC, Luzio JP (1982) What do ectoenzymes do? Trends Biochem Sci 7:145-147. https://doi.org/10.1016/ 0968-0004(82)90207-9

78. Chen J-F, Eltzschig HK, Fredholm BB (2013) Adenosine receptors as drug targets - what are the challenges? Nat Rev Drug Discov 12:265-286. https://doi.org/10.1038/nrd3955

79. Widnell CC, Kitson RP, Wilcox DK (1986) Ecto-5'-nucleotidase as a probe for the analysis of membrane flow during fluid phase pinocytosis. In: Kreutzberg GW, Reddington M, Zimmermann $\mathrm{H}$ 
(eds) Cellular biology of ectoenzymes. Springer-Verlag, Berlin, Heidelberg, NewYork, pp 117-132

80. Zimmermann H (1992) 5'-Nucleotidase: molecular structure and functional aspects. Biochem J 285(Pt 2):345-365. https://doi.org/ 10.1042/bj2850345

81. Misumi Y, Ogata S, Hirose S, Ikehara Y (1990) Primary structure of rat liver 5'-nucleotidase deduced from the cDNA. Presence of the $\mathrm{COOH}$-terminal hydrophobic domain for possible posttranslational modification by glycophospholipid. J Biol Chem 265:2178-2183

82. Misumi Y, Ogata S, Ohkubo K et al (1990) Primary structure of human placental 5'-nucleotidase and identification of the glycolipid anchor in the mature form. Eur J Biochem 191:563-569. https:// doi.org/10.1111/j.1432-1033.1990.tb19158.x

83. Volknandt W, Vogel M, Pevsner J et al (1991) 5'-nucleotidase from the electric ray electric lobe. Primary structure and relation to mammalian and procaryotic enzymes. Eur J Biochem 202:855861. https://doi.org/10.1111/j.1432-1033.1991.tb16443.x

84. Resta R, Yamashita Y, Thompson LF (1998) Ecto-enzyme and signaling functions of lymphocyte CD73. Immunol Rev 161:95109. https://doi.org/10.1111/j.1600-065x.1998.tb01574.x

85. Colgan SP, Eltzschig HK, Eckle T, Thompson LF (2006) Physiological roles for ecto-5'-nucleotidase (CD73). Purinergic Signal 2:351-360. https://doi.org/10.1007/s11302-005-5302-5

86. Minor M, Alcedo KP, Battaglia RA et al (2019) Cell type- and tissue-specific functions of ecto-5'-nucleotidase (CD73). Am J Physiol Cell Physiol 317:C1079-C1092. https://doi.org/10.1152/ ajpcell.00285.2019

87. Bianchi V, Spychala J (2003) Mammalian 5'-nucleotidases. J Biol Chem 278:46195-46198. https://doi.org/10.1074/jbc. R300032200

88. Knöfel T, Sträter N (2001) E. coli 5'-nucleotidase undergoes a hinge-bending domain rotation resembling a ball-and-socket motion. J Mol Biol 309:255-266. https://doi.org/10.1006/jmbi.2001. 4657

89. Sträter N (2006) Ecto-5'-nucleotidase: structure function relationships. Purinergic Signal 2:343-350. https://doi.org/10.1007/ s11302-006-9000-8

90. Heuts DPHM, Weissenborn MJ, Olkhov RV, Shaw AM, Gummadova J, Levy C, Scrutton NS (2012) Crystal structure of a soluble form of human CD73 with ecto-5'-nucleotidase activity. Chembiochem 13:2384-2391. https://doi.org/10.1002/cbic. 201200426

91. Knapp K, Zebisch M, Pippel J, el-Tayeb A, Müller CE, Sträter N (2012) Crystal structure of the human ecto-5'-nucleotidase (CD73): insights into the regulation of purinergic signaling. Structure 20:2161-2173. https://doi.org/10.1016/j.str.2012.10. 001

92. Corbelini PF, Figueiró F, das Neves GM et al (2015) Insights into ecto-5'-nucleotidase as a new target for cancer therapy: a medicinal chemistry study. Curr Med Chem 22:1776-1792. https://doi. org/10.2174/0929867322666150408112615

93. Servos J, Reiländer H, Zimmermann H (1998) Catalytically active soluble ecto-5'-nucleotidase purified after heterologous expression as a tool for drug screening. Drug Dev Res 45:269-276. https:// doi.org/10.1002/(SICI) 1098-2299(199811/12)45:3/4<269:AIDDDR25>3.0.CO;2-B

94. Junker A, Renn C, Dobelmann C, Namasivayam V, Jain S, Losenkova K, Irjala H, Duca S, Balasubramanian R, Chakraborty S, Börgel F, Zimmermann H, Yegutkin GG, Müller CE, Jacobson KA (2019) Structure-activity relationship of purine and pyrimidine nucleotides as ecto-5'-nucleotidase (CD73) inhibitors. J Med Chem 62:3677-3695. https://doi.org/10.1021/acs. jmedchem.9b00164
95. Bhattarai S, Pippel J, Meyer A, Freundlieb M, Schmies C, Abdelrahman A, Fiene A, Lee SY, Zimmermann H, el-Tayeb A, Yegutkin GG, Sträter N, Müller CE (2019) X-ray co-crystal structure guides the way to subnanomolar competitive ecto-5'-nucleotidase (CD73) inhibitors for cancer immunotherapy. Adv Therap 2:1900075. https://doi.org/10.1002/adtp.201900075

96. Bhattarai S, Pippel J, Scaletti E, Idris R, Freundlieb M, Rolshoven G, Renn C, Lee SY, Abdelrahman A, Zimmermann H, el-Tayeb A, Müller CE, Sträter N (2020) 2-Substituted $\alpha, \beta$-methyleneADP derivatives: Potent competitive ecto-5'-nucleotidase (CD73) inhibitors with variable binding modes. J Med Chem 63: 2941-2957. https://doi.org/10.1021/acs.jmedchem.9b01611

97. Geoghegan JC, Diedrich G, Lu X, Rosenthal K, Sachsenmeier KF, Wu H, Dall'Acqua WF, Damschroder MM (2016) Inhibition of CD73 AMP hydrolysis by a therapeutic antibody with a dual, non-competitive mechanism of action. MAbs 8: 454-467. https://doi.org/10.1080/19420862.2016.1143182

98. Hay CM, Sult E, Huang Q, Mulgrew K, Fuhrmann SR, McGlinchey KA, Hammond SA, Rothstein R, Rios-Doria J, Poon E, Holoweckyj N, Durham NM, Leow CC, Diedrich G, Damschroder M, Herbst R, Hollingsworth RE, Sachsenmeier KF (2016) Targeting CD73 in the tumor microenvironment with MEDI9447. Oncoimmunology 5:e1208875. https://doi.org/10. 1080/2162402X.2016.1208875

99. Perrot I, Michaud H-A, Giraudon-Paoli M et al (2019) Blocking antibodies targeting the CD39/CD73 immunosuppressive pathway unleash immune responses in combination cancer therapies. Cell Rep 27:2411-2425.e9. https://doi.org/10.1016/j.celrep.2019. 04.091

100. Thompson LF, Eltzschig HK, Ibla JC, van de Wiele CJ, Resta R, Morote-Garcia JC, Colgan SP (2004) Crucial role for ecto-5'-nucleotidase (CD73) in vascular leakage during hypoxia. J Exp Med 200:1395-1405. https://doi.org/10.1084/jem.20040915

101. Romio M, Reinbeck B, Bongardt S et al (2011) Extracellular purine metabolism and signaling of CD73-derived adenosine in murine Treg and Teff cells. Am J Physiol Cell Physiol 301:C530 C539. https://doi.org/10.1152/ajpcell.00385.2010

102. Koszalka P, Ozüyaman B, Huo Y et al (2004) Targeted disruption of CD73/ecto-5'-nucleotidase alters thromboregulation and augments vascular inflammatory response. Circ Res 95:814-821. https://doi.org/10.1161/01.RES.0000144796.82787.6f

103. Zlomuzica A, Burghoff S, Schrader J, Dere E (2013) Superior working memory and behavioural habituation but diminished psychomotor coordination in mice lacking the ecto-5'-nucleotidase (CD73) gene. Purinergic Signal 9:175-182. https://doi.org/10. 1007/s11302-012-9344-1

104. Allard B, Longhi MS, Robson SC, Stagg J (2017) The ectonucleotidases CD39 and CD73: novel checkpoint inhibitor targets. Immunol Rev 276:121-144. https://doi.org/10.1111/imr. 12528

105. Di Virgilio F, Sarti AC, Falzoni S et al (2018) Extracellular ATP and $\mathrm{P} 2$ purinergic signalling in the tumour microenvironment. Nat Rev Cancer 18:601-618. https://doi.org/10.1038/s41568-0180037-0

106. Chen S, Wainwright DA, Wu JD, Wan Y, Matei DE, Zhang Y, Zhang B (2019) CD73: an emerging checkpoint for cancer immunotherapy. Immunotherapy 11:983-997. https://doi.org/10.2217/ imt-2018-0200

Publisher's note Springer Nature remains neutral with regard to jurisdictional claims in published maps and institutional affiliations. 